\title{
Molekuler Docking tehadap Senyawa Eugenol dan Myricetin pada Tanaman Cengkeh (Syzygium aromaticum) sebagai Penghambat Pertumbuhan SARS-CoV-2
}

\author{
Yizreel Y. Gerungan, ${ }^{1}$ Billy J. Kepel, ${ }^{2}$ Fatimawali, ${ }^{2}$ Aaltje Manampiring, ${ }^{2}$ \\ Fona D. Budiarso, ${ }^{2}$ Widdhi Bodhi ${ }^{2}$
}

\author{
${ }^{1}$ Program Studi Pendidikan Dokter Fakultas Kedokteran Universitas Sam Ratulangi \\ Manado, Indonesia \\ ${ }^{2}$ Bagian Kimia Fakultas Kedokteran Universitas Sam Ratulangi Manado, Indonesia \\ Email : yizreelyosia@gmail.com
}

\begin{abstract}
Cloves contain many chemical compounds that can be used for health. COVID-19 is a disease that is shaking the world today. Many people feel the impact of this disease. Until now, there is no definite cure and vaccine for the handling of COVID19. Objective to determine the interaction between compounds in cloves (eugenol and myricetin) and the main protease COVID-19 (6LU7). This study use a molecular docking, method using 4 main applications: autodock tools, autodock vina, biovia discovery studio and open babel. This study showed that almost all amino acid residues in the eugenol and myricetin compounds worked on the 6LU7 active site. The binding affinity of eugenol compounds in clove plants does not exceed the binding affinity of remdesivir, a drug studied as a drug for handling COVID-19, while the binding affinity of myricetin compounds in cloves plant exceeds the binding affinity of remdesivir. In conclusion, myricetin compounds have better results for use as a growth inhibitor for COVID-19 than eugenol.
\end{abstract}

Key words: Cloves, COVID-19, molecular docking.

\begin{abstract}
Abstrak: Cengkeh memiliki banyak kandungan senyawa kimia yang dapat dimanfaatkan bagi kesehatan. COVID-19 merupakan penyakit yang mengguncang dunia saat ini. Banyak masyarakat yang merasakan dampak dari penyakit ini. Hingga saat ini belum ada obat dan vaksin yang pasti untuk penanganan COVID-19. Penelitian ini bertujuan untuk mengetahui interaksi antara senyawa pada cengkeh (eugenol dan myricetin) dengan main protease COVID-19 (6LU7). Jenis penelitian ini menggunakan metode molekuler docking dengan menggunakan 4 aplikasi utama: autodock tools, autodock vina, biovia discovery studio dan open babel. Hasil penelitian ini menunjukkan bahwa hampir semua residu asam amino pada senyawa eugenol dan myricetin bekerja pada sisi aktif 6LU7. Hasil binding affinity senyawa eugenol pada tumbuhan cengkeh tidak melebihi binding affinity dari remdesivir, obat yang diteliti sebagai obat penanganan COVID-19, sedangkan hasil binding affinity senyawa myricetin pada tumbuhan cengkeh melebihi binding affinity dari remdesivir. Simpulan penelitian ini ialah senyawa myricetin memiliki hasil yang lebih baik untuk digunakan sebagai penghambat pertumbuhan COVID-19 dari pada eugenol.
\end{abstract}

Kata kunci: Cengkeh, COVID-19, molekuler docking. 


\section{PENDAHULUAN}

Indonesia sejak dahulu dikenal kaya akan tanaman herbal dan banyak menggunakan berbagai macam tanaman herbal untuk pengobatan secara tradisional. ${ }^{1}$ Menurut jennifer (2015) sekitar $80 \%$ orang memilih mengonsumsi tanaman herbal untuk digunakan dalam pengobatan. $^{2}$ Salah satu tanaman yang berkhasiat yaitu tanaman cengkeh (Syzygium aromaticum). Tanaman ini digunakan sebagai obat-obatan, makanan, minuman bahkan dalam industri rokok kretek. Bagian tanaman yang dapat dimanfaatkan mulai dari bunga, tangkai bunga, dan daun cengkeh, di samping itu cengkeh memiliki aroma yang enak yang berasal dari minyak atsiri yang terdapat dalam jumlah yang cukup besar, ${ }^{3}$ Senyawa kimia yang terkandung dalam tumbuhan cengkeh antara lain Eugenol, trans(beta) karyofilen, alfa - humulen, eugenil asetat, karyofilen oksidan, trimetoksiasetofenon, vanillin, myricetin. ${ }^{4}$

Pada tanggal 31 desember 2019, WHO China melaporkan kasus pneumonia yang tidak diketahui etiologinya yang berasal dari kota Wuhan, provinsi Hubei, China. ${ }^{5}$ Pada akhir januari 2020 WHO menetapkan status Global Emergency pada kasus virus corona. dan pada 11 februari 2020 WHO menamakannya sebagai Coronavirus disease (Covid-19) dan nama virusnya yaitu Severe acute respiratory syndrome Corona Virus 2 (SARS-CoV-2). ${ }^{6}$ Dan sampai saat ini belum ada pengobatan yang spesifik dalam megobati penyakit ini.

Berdasarkan latar belakang tersebut, maka penelitian ini dilakukan untuk mengetahui molekuler docking senyawa eugenol dan myricetin sebagai penghambat pertumbuhan SARS-CoV-2.

\section{METODE PENELITIAN}

Penelitian ini dilakukan pada bulan September - Desember 2020. Molekuler docking senyawa kimia pada tumbuhan cengkeh (Syzygium aromaticum) dilakukan di Bagian Kimia, Fakultas Kedokteran Universitas Sam Ratulangi Manado. Jenis penelitian ini ialah in silico dengan metode komputerisasi. Sampel yang digunakan yaitu senyawa eugenol dan myricetin pada tanaman cengkeh. Dengan penambatan antara ligan atau senyawa dari tumbuhan cengkeh dan reseptor dari main protease COVID-19 diharapkan dapat terlihat seberapa besar tumbuhan cengkeh sebagai penghambat pertumbuhan SARS-CoV-2.

Alat yang digunakan berupa laptop HP dengan spesifikasi prosesor windows 10, AMD E2-7110 APU dengan AMD Radeon R2 grafik (4 CPUs) 1,8 GHz, RAM 4 GB. Perangkat lunak yang digunakan berupa AutoDock, AutoDock Vina, Open babel, Biovia Discovery Studio 2020.

Bahan yang digunakan yaitu Struktur tiga dimensi senyawa eugenol dan myricetin yang diperoleh dari Pubchem dan main protease COVID-19 (6LU7) diperoleh dari Protein Data Bank (PDB).

Senyawa eugenol dan myricetin yang akan dijadikan ligan diperoleh melalui situs website Pubchem kemudian download dengan format SDF 3D. Selanjutnya buka aplikasi open babel untuk mengubah format SDF menjadi PDB.

Reseptor COVID-19 diperoleh melalui situs website PDB (Protein Data Bank), kemudian download dengan format PDB. Selanjutnya buka aplikasi Discovery studio visualisasi untuk membersihkan reseptor yang masih kotor. Langkah pertama klik menu scrip kemudian pilih selection selanjutnya select water molekul dan yang terakhir tekan delete pada keyboard. Langkah kedua yaitu klik menu scrip kemudian pilih selection selanjutnya select ligan kemudian delete. Jika reseptor sudah bersih secara keseluruhan, langkah terakhir tekan pada menu file kemudian save as reseptor tersebut dalam format PDB.

Proses molecular docking menggunakan aplikasi Autodock tools dan Autodock vina. Struktur reseptor dan ligan yang telah dioptimasi secara terpisah disimpan dalam satu folder yang sama. Untuk molekular docking menggunakan autodock tools terlebih dahulu dengan mempersiapkan reseptor tahapan sebagai berikut: buka aplikasi autodock tools kemudian klik read molecular pada menu 
file dan pilih reseptor yang akan didocking. Reseptor kemudian ditambahkan dengan hydrogen dan centang pada pilihan all hydrogen, method noBondorder, yes renumber atom in clude new hydrogen, kemudian klik OK. Setelah reseptor sudah ketambahan hydrogen, klik grid macromolekuler kemudian klik choose lalu klik reseptor dan terakhir select molekul. Reseptor tersebut disimpan dengan format PDBQT. Selanjutnya untuk persiapan ligan tahapannya sebagai berikut: klik ligan lalu klik input kemudian klik open dan pilih ligan yang ada pada folder. Selanjutnya jika ligan sudah keluar pada layer kerja klik torsion tree untuk mengatur number of Torsion pada ligan, kemudian simpan ligan dalam format PDBQT.

Hal yang selanjutnya dilakukan yaitu mempersiapkan tempat untuk ligan menambat pada reseptor. Langkah-langkah yang akan dilakukan yaitu pilih reseptor format PDBQT kemudian memasukan asam amino dari main protease SARSCoV-2 yang diperoleh dari Computed Atlas of Surface Topography of proteins dengan cara klik reseptor kemudian klik chain A. Klik grid box pada menu grid, selanjutnya sesuaikan number of Point pada sumbuh $\mathrm{x}$ (merah), y (hijau), z (biru), spacing (angstrom) dan center x (merah), y (hijau), $\mathrm{z}$ (biru) hingga setiap asam amino berada dalam tempat penambatan. Hal ini merupakan metode blind docking.

Langkah selanjutnya yaitu buka aplikasi Notepad dan masukan data-data seperti reseptor, ligan, out, center $\mathrm{x}$, center $\mathrm{y}$, center $\mathrm{z}$, size $\mathrm{x}$, size $\mathrm{y}$, size $\mathrm{z}$, dan keakuratan, kemudian simpan di folder yang telah dibuat. Selanjutnya masukan aplikasi autodock vina yang terdiri dari vina, vina split dan vina license pada folder yang telah dibuat, kemudian buka aplikasi Command prompt dan masukan format (contoh: C:luser $\backslash$ Costumer> D: $\backslash$ cd vina.), lalu masukan rumus untuk perhitungan dalam command prompt: vina --config conf.txt --log log.txt maka akan terdapat hasil binding affinity dari ligan yang diteliti. Setelah itu gunakan vina split untuk memisahkan hasil dari ligan satu per satu dengan menggunakan rumus vina_split -input out.pdbqt. Tahap terakhir yaitu visualisasi dengan cara drag reseptor dan out ligan 1 pada Discovery studio visualisasi kemudian lihat hasilnya dalam bentuk 2D dan 3D.

\section{HASIL PENELITIAN}

Sebelum dilakukan proses molekuler docking senyawa atau ligan yang digunakan akan di nilai sifatnya terlebih dahulu menggunakan aturan Lipinski. Aturan Lipinski dapat menentukan sifat fisiokimia ligan untuk memenuhi karakter hidrofobik atau hidrofilik suatu senyawa melalui membrane sel oleh difusi pasif. Adapun aturan Lipinski adalah (1) berat molekul kurang dari $500 \mathrm{Da}(2)$ nilai $\log \mathrm{P}$ kurang dari 5, (3) jumlah donor ikatan hydrogen kurang dari 5, dan (4) jumlah akseptor ikatan hydrogen kurang dari $10{ }^{7}$

Berdasarkan aturan Lipinski, senyawa eugenol dan myricetin memiliki berat molekul kurang dari $500 \mathrm{Da}$, nilai donor maupun akseptor ikatan hydrogen dan nilai $\log \mathrm{P}$ memenuhi kriteria dari aturan Lipinski.

Table 1 menunjukkan hasil molecular docking senyawa eugenol terhadap main protease COVID-19 (6LU7) dan senyawa myricetin terhadap main protease COVID19 (6LU7).

Table 1. Binding affinity senyawa eugenol dan myricetin

\begin{tabular}{lc}
\hline Ligand & Binding affinity \\
\hline Eugenol & -4.9 \\
Myricetin & -7.3 \\
\hline
\end{tabular}

Hasil Visualisasi yang didapatkan baik dalam bentuk 3D dan bentuk 2D antara ligan eugenol dan reseptor main protease COVID-19 (6LU7) melalui aplikasi biovia discovery studio visualisasi diperoleh yaitu terdapat beberapa jenis interaksi ikatan seperti ikatan van der waals, conventional hydrogen-Bond, carbon hydrogen bond, unfavorable acceptor acceptor, Pi-Donor hydrogen bond, Alkyl, Pi-Alkyl, sedangkan hasil visualisasi ligan myricetin terdapat beberapa jenis interaksi ikatan berupa 
ikatan van der waals, conventional hydrogen bond, carbon hydrogen bond, unfavorable donor-donor, Pi-Sulfur, PiAlkyl.

\section{BAHASAN}

Berdasarkan hasil visualisasi molekuler docking senyawa eugenol dan myricetin yaitu terdapat beberapa jenis ikatan. Ikatan van der Waals dan conventional hidrogen bond merupakan kedua jenis interaksi ikatan yang terdapat pada hasil docking kedua senyawa tersebut. Ikatan hidrogen merupakan salah satu faktor yang mempengaruhi kestabilan protein. ${ }^{8}$

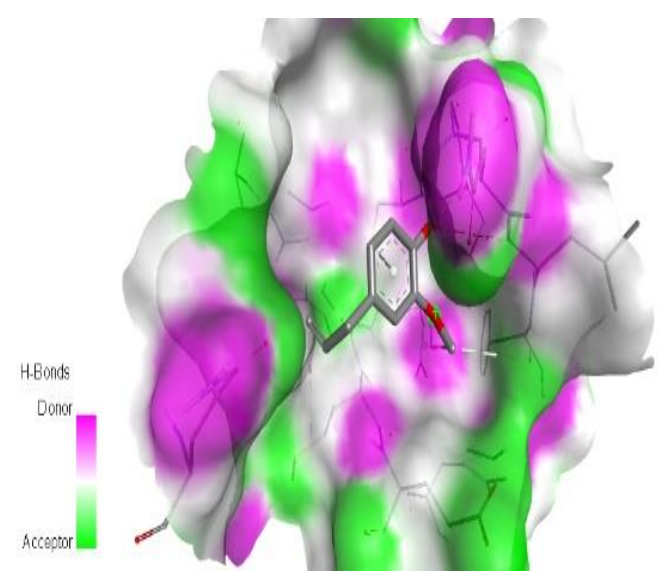

Gambar 1. Visualisasi dalam bentuk 3D hasil molekuler docking ligan eugenol dan reseptor 6LU7

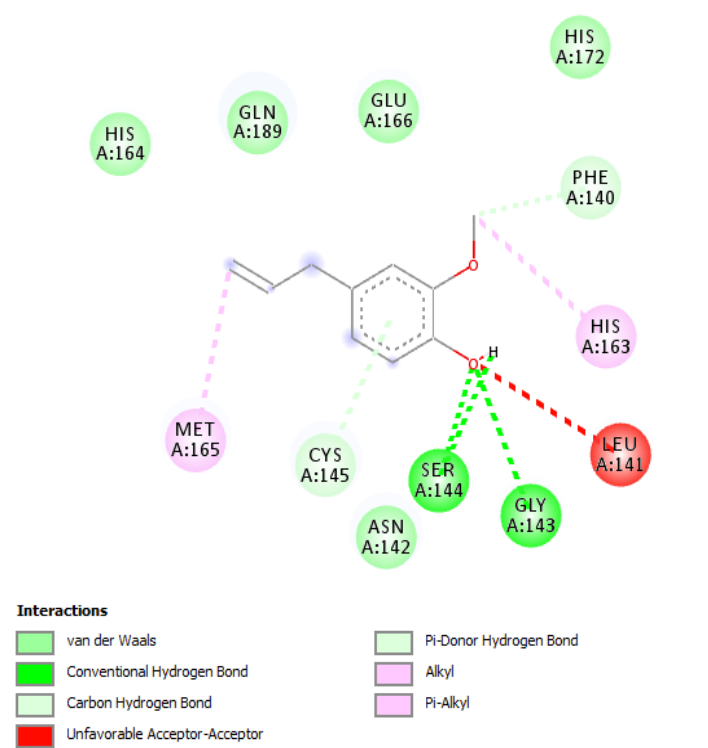

Gambar 2. Visualisasi dalam bentuk 2D hasil molekuler docking ligan eugenol dan reseptor 6LU7

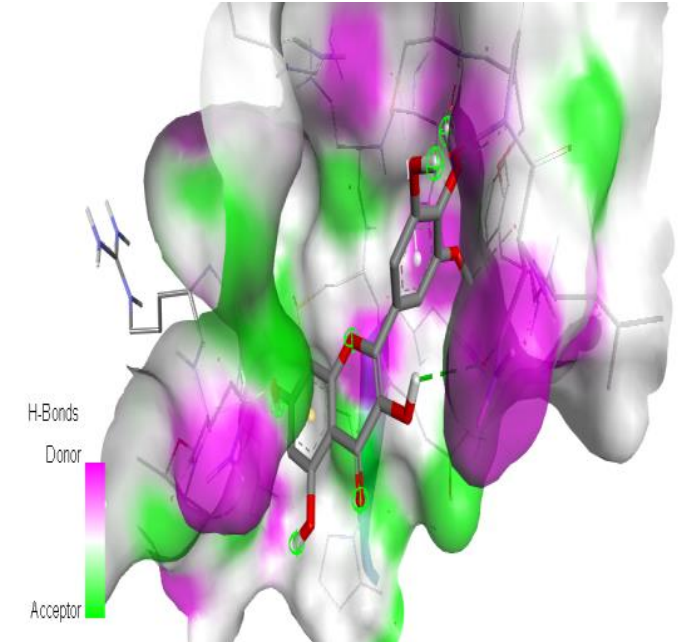

Gambar 3. Visualisasi dalam bentuk 3D hasil molekuler docking ligan myricetin dan reseptor 6LU7.

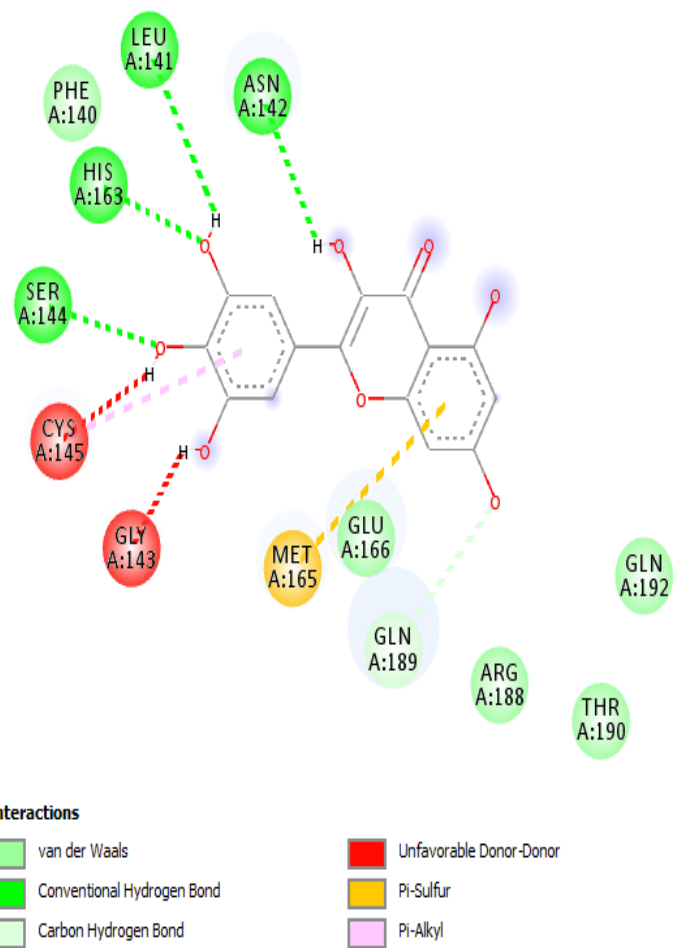

Gambar 4. Visualisasi dalam bentuk 2D hasil molekuler docking ligan myricetin dan reseptor 6LU7.

Berdasarkan hasil dari Computed Atlas of Surface Topography of proteins menunjukkan bahwa sisi aktif makromolekul dari main protease SARSCoV-2 yaitu terdapat 18 asam amino residu berupa THR24, THR25, THR26, LEU27, HIS41, CYS44, THR45, SER46, MET49, 
PHE140, LEU141, ASN142, GLY143, SER144, CYS145, HIS163, MET165, GLU166, HIS172. Residu asam amino dari senyawa eugenol yang bekerja di sisi aktif main protease COVID-19 (6LU7) yaitu PHE140, LEU141, ASN142, GLY143, SER144, CYS145, HIS163, MET165, GLU166, HIS172. Residu asam amino dari senyawa myricetin yang bekerja disisi aktif main protease COVID-19 (6LU7) yaitu PHE140, LEU141, ASN142, GLY143, SER144, CYS145, HIS163, MET165, GLU165. Hal ini menunjukkan bahwa hampir semua residu asam amino dari senyawa eugenol dan myricetin bekerja pada sisi aktif dari main protease SARSCoV-2.

Obat remdesivir yang dijadikan sebagai kontrol positif mendapatkan hasil binding affinity yaitu -7.2. Hal tersebut menunjukan bahwa senyawa eugenol memiliki hasil yang lebih rendah dari pada remdesivir sedangkan senyawa myricetin memiliki hasil yang lebih tinggi dari pada remdesivir.

\section{SIMPULAN}

Senyawa myricetin memiliki hasil yang lebih baik untuk digunakan sebagai penghambat pertumbuhan SARS-CoV-2 daripada senyawa eugenol.

\section{SARAN}

Hasil ini merupakan aktivitas biologis karena didapati dari penelitian software. Sehinggan perlu dilakukan uji in vitro dan in vivo untuk mengetahui aktivitas senyawa-senyawa tersebut. Perlu dilakukan penelitian lebih lanjut mengenai senyawa myricetin sebagai penghambat pertumbuhan SARS-CoV-2 sehingga mendapatkan hasil yang maksimal terhadap kerja dari senyawa myricetin.

\section{Konflik Kepentingan}

Penulis menyatakan tidak terdapat konflik kepentingan dalam studi ini.

\section{DAFTAR PUSTAKA}

1. Ana YU. Obat Tradisional [Diktat]. Jambi: Jurusan Keperawatan Universitas Jambi. 2012.

2. Jennifer H, Saptutyningsih E. Preferensi Individu Terhadap Pengobatan. Jurnal Ekonomi dan Studi Pembangunan, 2015;16(1): 26-41.

3. Nurdjannah N. Diversifikasi Penggunaan Cengkeh. Perspektif. 2016; 3(2):61-70.

4. Mittal M, Gupta N, Parashar P, Mehra V, Khatri M. Phytochemical evaluation and pharmacological activity of syzygium aroma-ticum: A comprehensive review. Int $\mathbf{J}$ Pharm Pharm Sci 2014;6(8):6772.

5. WHO. Novel Coronavirus (2019-nCoV) Situation Report - 1. Who [Internet]. 2020;(JANUARY):1-7. Available from: https://www. who.int/docs/defaultsource/coronaviruse/situationreports/20200121-sitrep-1-2019ncov.pdf?sfvrsn=20a99c10_4

6. Gorbalenya AE, Baker SC, Baric RS, de Groot RJ, Drosten C, Gulyaeva AA, et al. The species Severe acute respiratory syndrome-related coronavirus: classifying 2019$\mathrm{nCoV}$ and naming it SARS-CoV2. Nat Microbiol. 2020;5(4):53644.

7. Syahputra G, Ambarsari L, Sumaryada T. Simulasi Docking Kurkumin Enol , Bismetoksikurkumin Dan Analognya Sebagai Inhibitor Enzim12-Lipoksigenase. Jurnal Biofisika 2014;10(1):55-67.

8. Fu Y, Zhao J, Chen Z. Insights into the molecular Mechanisms of ProteinLigand Interactions by Molecular Docking and Molecular Dynamics Simulation: A Case of Oligopeptide Binding Protein. Comput Math Methods Med. 2018;2018. Article ID 3502514, 12 pages. Available from:https://doi.org/10.1155/2018/ 3502514 